IJMS 18 (1), 71-97 (2011)

\title{
THE INFLUENCE OF ORGANIZATIONAL CULTURE AS MODERATOR BETWEEN PERSON-ORGANIZATION (P-O) FIT AND WORK ATTITUDES
}

\author{
S. SENTHIL KUMAR \\ IBS, Hyderabad, India
}

\begin{abstract}
Although the positive effect of Person-Organization fit (P-O fit) on work attitudes is well known, research into the environmental factors that affect $P-O$ fit's salience in predicting work attitudes is in its infancy. This study examined the moderating effects of organizational culture in the relationship between $P-O$ fit and work attitudes such as job satisfaction, and organizational commitment in the national culture context. Results from a sample of 173 managerial-level employees from 7 organizations in India suggest that organizational culture either strengthens or weakens the positive relationship between $P-O$ fit and work attitudes depending upon its alignment with national culture. In the Indian cultural context, it is found that people and control-oriented organizational cultures that are isomorphic with national culture weaken the relationship between $P-O$ fit and work attitudes. Whereas creation and market-oriented cultures that are nonisomorphic with Indian national culture strengthen the positive relationship between P-O fit and work attitudes. Results of this study have implications in employee selection, socialization and organizational culture management.
\end{abstract}

Keywords: Person-organization fit, organizational culture, national culture, job satisfaction, organizational commitment.

\section{Introduction}

Beginning with Lewin's (1951) proposition that behaviour is a function of both person and environment, researchers have developed various theoretical models to explain organizational behaviour. Traditionally the construct of Person-Organizationt Fit (P-O Fit) has been used to analyse the relationship between individuals and the organizational environments in which they find themselves (Kristof, 1996). P-O fit is defined as similarity between 
the characteristics of people and the corresponding characteristics of organizations (Chatman, 1989; Kristof, 1996) and distinguished from other forms of Person-Environment fit such as Person-Job fit, Person-Vocation (P-V) fit (e.g., Holland, 1985), Person-Group (P-G) fit (e.g., Guzzo \& Salas, 1995) and Person-Job (P-J) fit (e.g., Edwards, 1991). The basic premise of the (P-O) fit theory and research is that when characteristics of people and work environment are matched, positive organizational outcomes such as job satisfaction, organizational commitment, and reduced turnover intentions would result.

Although the term "person-organization (P-O) fit" has been used to describe the congruence between individual and organizational goals; individual needs or demands and organizational systems or supplies; and individual personality and organizational climate (see Kristof, 1996), the majority of P-O fit research has been focused on the similarity between individual and organizational values (Cable \& Judge, 1996, 1997; Chatman, 1991; O'Reilly, Chatman \& Caldwell, 1991). In particular Chatman and her colleagues worked on value congruence as a prominent one among others. Chatman (1989) proposed a model of person-organization fit with specific theoretical propositions on antecedents, processes and consequences of the model. Since then several studies have provided theoretical justification as well as empirical evidence for the positive association between $\mathrm{P}-\mathrm{O}$ fit and organizational outcomes. Results of these studies have generally shown significant positive relationships between P-O fit and work attitudes such as job satisfaction and organizational commitment (Chatman, 1991; O’Reilly et al., 1991).

Human resource practices affect employees' work attitudes first and these cognitions will in turn elicit desired organizational behaviours such as low absenteeism, organizational citizenship behaviour, and work performance. Work attitude predisposes an individual to behave in a particular way. Job satisfaction and organizational commitment are widely researched examples of work attitudes. Job satisfaction is a general work-related attitude. It refers to the overall attitude that an employee has towards both the job content and its context. The context typically includes pay, promotion, recognition, communication, co-workers, supervisors, and benefits. Organizational commitment refers to the strength of the employee's involvement and identification with the organization. Organizational commitment includes the three components: affective, continuance and normative (Meyer, Allen \& Smith, 1993). The affective component describes how the employee is emotionally attached to the organization and

72 IJMS 18 (1), 71-97 (2011) 
thus wishes to remain with it. The continuance component refers to the extent to which the employee perceives the need to stay in the organization. The employee may want to stay in the organization because he or she needs the pay, benefits, or cannot find another job. The normative component refers to the perceived obligation on the part of the employee to stay in the organization. Research suggests that organizational commitment is directly related to employee involvement, intention to stay with the organization as well as job performance (Mathieu \& Zajac, 1990). Since both job satisfaction and organizational commitment have been identified as "important variable(s) in understanding the work behaviour of employees in organizations" (Mowday, Steers \& Porter, 1979, pp. 225) the current study examines how P-O fit affects these work attitudes.

\section{Research Objective}

Since P-O fit is assessed on a variety of individual and organizational characteristics, the relevance of fit on any of these characteristics is dependent upon how important that characteristic is to the individual and the organization (Kristof, 1996). P-O fit's positive effect may be moderated by environmental characteristics such as organizational culture and national culture. If organizational culture itself exerts considerable influence over individual work behaviour then P-O fit may become less relevant in predicting work attitudes. The research objective of the current study is to examine the moderating effects of certain types of organizational culture, depending upon their alignment with the characteristics of national culture, on the relationship between P-O fit and work attitudes.

\section{Significance of the Study}

Macro level variables such as national culture, socio-economic conditions, particularly labour market conditions that prevail in a country may also influence P-O fit's effects on work attitudes. Most of the studies of P-O fit have been carried out in the U.S. where the social, economic, political and cultural characteristics are vastly different from developing countries. The American approach to work is that loyalty from employee to the organization or from the organization to the employee tends to be based on self-interest, and is short lived and nonexistent in most instances (Friedman \& Friedman, 1980). Many Americans derive individual identity with his/her occupation/career rather than the organization. Given the number of employment opportunities, attracting and retaining employees is a challenging 
task. In such a context, $\mathrm{P}-\mathrm{O}$ fit is often touted as a predictor of favourable work attitudes, job performance, lower absenteeism and turnover (Bowen, Ledford \& Nathan, 1991).

However, the nature of organizational problems that managers in developing economies face are different from that of developed economies. Unlike in developed economies, the immediate concern for managers in developing economies is organizational survival rather than competitiveness via human resources (Pieper, 1990). Nyambegera, Daniels and Sparrow (2001), in a study conducted in African context, have shown that individuals value themselves and not the P-O fit which are important in predicting job involvement in the context of developing countries. They argue that in a developing economy context that is characterized by high levels of unemployment, excess supply of cheap unskilled labour, the managers' chief concern would be organizational survival. In the Indian context, results of a recent research (Budhwar \& Sparrow, 2002) suggest that, due to the severe pressure created by continuous liberalizations of economic policies and the increasing presence of foreign players, the question of immediate survival has become more important among Indian organizations. In such situations P-O fit as presented in developed economies may not matter in predicting employees' work attitudes.

It is not clear then that constructs such as P-O fit can predict work attitudes in developing contexts such as India. Recent research conducted with Indian and U.S samples by Westerman and Sita (2005) suggests that the effects of P-O fit may not only be affected by the organizational environment but the national culture as well. In their study, the congruence between a student's preferred classroom environment and the perceptions of the actual work environment was found to be a significant predictor of student satisfaction and performance only in the U.S group and not in the Indian sample. The authors further observed that the norms of high power distance and collectivistic behaviour in India may facilitate conformity and suppression of individual differences in work environment attitudes and behaviours, thus reducing the relationship between P-O fit and work place outcomes. Since their study was conducted in the higher educational institutions, further empirical studies are required before we extend the results to build theory on the interaction among organizational culture, national culture and $\mathrm{P}-\mathrm{O}$ fit in the organizational context. Although it is intuitively appealing to expect macro-level factors such as national culture, economic and labour market conditions to reduce the importance of $\mathrm{P}-\mathrm{O}$ fit, it is also plausible to reason that certain meso-level factors such as organizational culture to counteract the forces of macro-level factors so that P-O 
fit's salience is increased. Clearly understanding the predictability of $\mathrm{P}-\mathrm{O}$ fit in the developing countries context can help in implementing suitable human resource management practices. The present study assumes significance in extending this line of research by examining the moderating effects of organizational culture in the relationship between P-O fit and work attitudes within the macro-level context of Indian national culture.

The rest of the paper is organized as follows. In the next section, a review of the literature leading to the hypotheses is presented. Then the operationalization of variables and the method to test the hypotheses are presented. After that the data are described and results are discussed. Finally the paper concludes with a discussion on research findings as well as directions for future research.

\section{Literature Review}

\section{Person-Organization (P-O) Fit and its Effect on Work Attitudes}

Research interest on Person-Organization fit is an outgrowth of the idea that organizations have cultures that may be attractive or unattractive to certain types of individuals (Wilkins \& Ouchi, 1983). $\mathrm{P}-\mathrm{O}$ fit is conceptualized either with a supplementary perspective or a complementary perspective (Kristof, 1996). A supplementary fit occurs when organizational characteristics such as culture, values, goals, and norms are aligned with individual characteristics such as personality, values, goals and attitudes. A complementary fit results when an organization fulfils an individual's needs, desires and preferences and/or an individual has the abilities to meet organizational demands. The dynamic process that leads to the supplementary type of $\mathrm{P}-\mathrm{O}$ fit was described by Schneider's (1987) attraction-selection-attrition (ASA) framework, which posits that similar people are attracted to and then selected and retained by the organization. Researchers typically examined $\mathrm{P}-\mathrm{O}$ fit from the supplementary fit perspective. $\mathrm{P}-\mathrm{O}$ fit is defined as the "congruence between the norms and values of organizations and the values of persons" (Chatman, 1989, pp. 339).

Employee attitudes related to job satisfaction and organizational commitment are the most important and frequently studied variables due to their significant implications to the field of organizational behaviour and human resource management. Job satisfaction is defined as "a pleasurable or positive emotional state resulting from the appraisal of one's job or job experience." (Locke, 1976, pp. 1300). Job satisfaction represents an employee's global evaluation of the work,

IJMS 18 (1), 71-97 (2011) 75 
pay, promotion opportunities, supervision and co-workers support. Research evidence shows that job satisfaction affects employee work behaviour significantly. Job satisfaction is found to be positively related to job performance (Harter, Schmidt \& Johnson, 2002), customer satisfaction (Griffith, 2001) and inversely related to absenteeism (Scott \& Taylor, 1985) and turnover (Griffeth, Hom \& Gaertner, 2000).

Organizational commitment refers to the strength of the employee's attachment to the organization. Organizational commitment can be defined as "the relative strength of an individual's identification with an involvement in a particular organization" (Mowday et al., 1979, pp. 226). Organizational commitment includes the three components: affective, continuance and normative (Meyer et al., 1993). The affective component describes how the employee is emotionally attached to the organization and thus wishes to remain with it. The continuance component refers to the need level of the employee to stay in the organization. The employee may want to stay in the organization because he or she needs the pay, benefits, or cannot find another job. The normative component refers to the perceived obligation on the part of the employee to stay in the organization. Organizational commitment is directly related to employee involvement, intention to stay with the organization as well as job performance (Mathieu \& Zajac, 1990). Research has shown strong support for the positive effects of P-O fit on job satisfaction and organizational commitment (Chatman, 1991; O’Reilly et al., 1991).

\section{Organizational Culture}

Beginning with Pettigrew's (1979) work on culture as an anthropological concept that can be used in organizational analysis, the construct of organizational culture has received a great deal of attention among management researchers. Organization culture has been defined as the widely shared and strongly held values by the employees (Chatman \& Jehn, 1994), and shared perceptions of work practices (Hofstede, 2001). Since values act as the core elements of culture whereas norms, symbols, rituals and other culturally-related activities support them (Enz, 1988), organizational culture can be said to exist when the members of the organization share some common values (Weiner, 1988).

\section{National Culture}

On a national level "culture" refers to a set of values, beliefs, assumptions, expectations, perceptions and behaviours that is commonly shared by most of the people in a society. Hofstede (1991,

76 IJMS 18 (1), 71-97 (2011) 
pp. 5) defined culture as "the collective programming of the mind that distinguishes the members of one group of category of people from another." He described national cultures of different countries using five dimensions: individualism-collectivism, power distance, uncertainty avoidance, masculinity-femininity, short-term vs. longterm orientation.

\section{Interaction Effects}

Research interest in the interaction effects of $\mathrm{P}-\mathrm{O}$ fit with organizational culture on organizational outcomes has grown since the research conducted by Sheridan (1992). His study investigated the influence of organizational culture values on the retention rates of 904 college graduates hired by six large accounting firms in the USA over a six-year period. Results showed that turnover rate was high in the cultures emphasizing attention to detail and stability values to those cultures emphasizing team orientation and respect for people values. Although this study did not measure individual values, the interpretation of the results made by Sheridan (1992) suggested that $\mathrm{P}-\mathrm{O}$ fit may have less influence on organizational outcomes than situational effects such as specific organizational cultural values. Further empirical support to Sheridan's (1992) assertion was provided by a study conducted in Taiwanese context (McKinnon, Harrison, Chow \& Annue, 2003). P-O fit was shown to be less effective on work attitudes than innovation, respect for people, stability and aggressiveness-oriented organizational culture thus indicating some cross-cultural generalizability of Sheridan's (1992) findings as well.

Research evidence on the influence of national culture on organizational culture is sparse. Organizational theorists have long argued for the plausibility of organizational culture to reflect the national culture characteristics. Much of the support for the argument is rooted in institutional, population-ecology, and contingency theories (DiMaggio \& Powell, 1983; Meyer \& Rowan, 1977). According to the proponents of these theories, organizations must be isomorphic with their environments in order to survive and prosper. Organizational culture is largely shaped by widely held beliefs and values of the members of the organization (Chatman, 1991). Since national cultures affect individual values (Hampden-Turner \& Trompenaars, 1993) and beliefs (Smith \& Thomas, 1972), one may expect some sort of isomorphic relationship between organizational culture and national culture. Jabes and Gruere (1986) argue that an organization's members will hold values that tend to be, on average, similar to those of their nation's culture. Hofstede's (1985) research 
showed that organizational value system exhibited national culture characteristics.

Although environment creates pressures on organizations to move toward isomorphism, there are other forces, both internal and external, that act on organizations to develop non-isomorphic relationship with their environment. The argument that organizations develop separate identity which distinguishes them from the environment through boundary-maintaining mechanisms (Aldrich, 1979; Argyris, 1964; Katz \& Kahn, 1966) suggests that organizational culture need not be aligned with national culture. Further organizational cultures may differ from national culture because of the influence of: a) industry characteristics (Gordon, 1991; Chatman \& Jehn, 1994), b) task and market characteristics (Hofstede, 2001) and c) absence of institutional alternatives (Wilkins \& Ouchi, 1983). In this regard, results of recent empirical research suggest that the relationship between organizational culture and national culture is rather complex than simple. In a study aimed to examine whether organizational cultures replicate national cultures, Nelson and Gopalan (2003) found that some organizations tend to be isomorphic through replicating national culture characteristics, some had cultures that are reciprocally opposite to national cultures while others had cultures that are independent of national culture. We can see then, that organizations vary in their intent, processes, and capacity to nurture their cultures in alignment with national culture.

The basic premise of this paper is that $\mathrm{P}-\mathrm{O}$ fit's positive effect on work attitudes may be contingent upon the nature of organizational culture dimensions and their alignment with national culture. P-O fit may not predict work attitudes to the extent that organizational culture is isomorphic with national culture. This is because organizational cultural values themselves and not the $\mathrm{P}-\mathrm{O}$ fit, will engender positive associations with work attitudes (McKinnon et al., 2003). Hence it may be expected that in the presence of organizational cultures that are isomorphic with Indian national culture, P-O fit may lose its salience in predicting work attitudes.

However, if organizational culture is strong (i.e., those with an identifiable set of norms, values, and beliefs; Schein, 1992) and nonisomorphic to the characteristics of national culture, then $\mathrm{P}-\mathrm{O}$ fit may assume importance in predicting positive work attitudes. This is because while organizations strive to create their own unique and strong cultures which are different from the prevailing national culture values, they may often achieve high levels of P-O fit through careful selection and highly institutionalized socialization processes 
(Chatman, 1991; Cable \& Parsons, 2001). Pascale (1985) discussed how strong culture firms use the socialization process to achieve high levels of $\mathrm{P}-\mathrm{O}$ fit. He observed that strong culture firms "rely heavily on the informed applicant deselecting himself if the organization doesn't fit with his personal style and values"(pp. 29). Further, results of recent research indicate that the national culture influence is stronger on personally-held managerial work values (Ralston, Holt, Terpstra \& Cheng, 2008). If organizational values are different from that of personal values, then individuals will be more likely to change their personal values only when they confront organizations that have strong cultures (Chatman, 1989). Hence it is logical to expect the organizations to rely heavily on their selective hiring, socialization, and rewarding processes in order to develop cultures that are non-isomorphic with national cultures. People's response to $\mathrm{P}-\mathrm{O}$ fit is increased only in such organizations because "...the more clearly organizational values and culture can be identified and the more explicitly they are hired for, measured, and rewarded, the more important P-O fit should be..." (Kristof \& Jansen, 2007, pp.128). Hence it may be expected that in the presence of organizational cultures that are non-isomorphic with national culture, P-O fit may gain its salience in predicting work attitudes.

Using Quinn and Rohrbaugh's (1983) competing values framework, organizational culture dimensions as proposed by the Organizational Culture Profile (OCP) (O'Reilly et al., 1991) can be classified into four groups: a) creation, b) people, c) control and d) market. The competing values framework consists of two dimensions: a) flexibility vs. stability and b) internal oriented vs. external oriented. Creation types of organizational cultures are flexible and external oriented. People-oriented cultures are flexible but internal oriented. Controloriented cultures are internal focused but stability is maintained. Market-oriented cultures are stability focused but external focused. Two of the OCP dimensions described norms regarding Creation: a) innovation - This dimension includes three values describing norms of risk taking, openness to change and being experimental in the organization; b) flexibility - This dimension includes five values that describe norms of adaptability and not being constrained by many rules. Two dimensions describe norms regarding people: c) team orientation - This dimension includes five values describing norms regarding collaboration and supporting each other in the organization; d) People-orientation dimension includes three values describing interpersonal relationship, respecting individual's right and fairness in dealing with people in the organization. Two dimensions describe norms regarding control: e) stability - This dimension includes three values describing predictability and security of employment.

IJMS 18 (1), 71-97 (2011) 79 
Four dimensions describe norms regarding market: $\mathrm{f}$ ) attention to detail - This dimension includes four values that describe analytical, precision and detail orientation in the organization; g) performance orientation - This dimension includes four values that describe norms of high expectations for performance; $h$ ) decisiveness - This dimension includes three values describing decisive orientation in the organization; i) competitiveness - This dimension includes four values that describe aggressive competition; and j) organizational reputation - This dimension includes six values describing corporate social responsibility and organizational reputation. Since both internal and external stakeholders are affected by organizational reputation, one can classify this dimension into both people and market types of organizational culture. The following section describes the development of hypotheses specific to Indian cultural context.

\section{Hypothesis Development}

India is a republic in South Asia. It is the second-most populous country in the world with its population crossing 1 billion mark in June 2000. Economic reforms since 1991 have transformed it into as one of the world's fastest growing economies. However, it still suffers from high levels of hunger, poverty, malnutrition, illiteracy, and unemployment (Economic survey, Government of India, 2008-09). According to the United Nations Development Program Statistical Update (2009), India is ranked at 134 out of 182 countries in the world in terms of Human Development Index (HDI). The prevailing values, beliefs, and behavioural patterns which form part of Indian national culture can be attributed to several factors. Feudalistic values promoted by British, during their rule over India for more than a century, along with the caste system promoted hierarchy, status consciousness, power distance and low individualism in India (Saini \& Budhwar, 2004).

Individuals in India derive their identity based on family and caste membership. The group is considered to be more important than the individual (Prakash, 1994; Tripathi, 1988). Collective goals are prioritized over individual goals and desires. Hierarchy and status shape relationships which are usually long lasting. . The Indian social and cultural environments place high value on strong family ties, giving respect to elderly people resulting in greater dependence on others. Thus interpersonal relationship assumes greater importance in people management in India (Saini \& Budhwar, 2004). Since Indian national culture values inter-personal relationship and group ties, it is expected people-oriented organizational culture will negatively moderate the relationship between $\mathrm{P}-\mathrm{O}$ fit and work attitudes.

80 IJMS 18 (1), 71-97 (2011) 
Hypothesis 1: Organizational culture moderates the positive relationship between P-O fit and organizational commitment and job satisfaction in such a way that the relationship will be weaker when the culture is more oriented towards people.

While Sheridan's (1992) study found that the cultural dimension stability is positively associated to a higher turnover rate among the employees in his Anglo-American cultural context. One of the three values comprising Stability is security of employment. It may be argued that, due to cultural differences between the U.S and India, the importance given to the value of security of employment varies between the employees in the U.S and the Indian firms. The U.S. is a highly individualistic and short-term oriented culture. In this culture, Hofstede (2001) notes that "the relationship between employer and employee is primarily conceived as a business transaction, a calculative relationship between actors on a "labour market." Americans tend to identify themselves by their occupations or professions (Adler, 1997). Employees are more loyal to their profession than to their organization. Job hopping and layoff are fairly common. However, India is a low individualist (collectivist) and long-term oriented culture (Hofstede, 2001). In this culture, employees have a moral involvement with their organization and place more emphasis on their job security. Employers and employees are more inclined to show loyalty and develop long-term relationships although job hopping has become increasingly common among the younger generation (Gopalan \& Stahl, 1998). Moreover given the relatively high uncertainty-avoidance nature of Indian culture (Kanungo \& Mendonca, 1994), it is expected that control-oriented organizational culture such as control to negatively moderate the relationship between $\mathrm{P}-\mathrm{O}$ fit and work attitudes.

Hypothesis 2: Organizational culture moderates the positive relationship between $\mathrm{P}-\mathrm{O}$ fit and organizational commitment and job satisfaction in such a way that the relationship will be weaker when the culture is more oriented towards control.

Kanungo and Mendonca (1994) have shown significant cultural differences between Indian and western countries on the basis of Hofstede's (1991) fourinitial dimensions of power distance, uncertainty avoidance, individualism, and masculinity. India is positioned relatively high on uncertainty avoidance and power distance and relatively low on individualism and masculinity dimensions. Relatively high uncertainty avoidance implies an unwillingness to take risks and more resistance to organizational change. Further most

IJMS 18 (1), 71-97 (2011) 81 
(if not all) Indians believe that life is predetermined (according to the principle of reincarnation which is a fundamental belief in Hinduism) and that change is relatively difficult to accomplish (Saha, 1992; Kuppuswamy, 1994). In a cultural environment where widespread sense of fatalism prevails, individuals have little perceived control over events because of their belief that things will happen anyway. In such context organizations may also be less proactive and innovation oriented. Since Indian culture is characterized by relatively high uncertainty avoidance and fatalism, it is expected that in the presence of creation-oriented organizational cultures such as innovation and flexibility the salience of $\mathrm{P}-\mathrm{O}$ fit is increased to strongly predict work attitudes.

Hypothesis 3: Organizational culture moderates the positive relationship between $P-O$ fit and organizational commitment and job satisfaction in such a way that the relationship will be stronger when the culture is more oriented towards creation.

The relative low individualism implies that family and group are preferred over work outcomes (Sharma, 1984). Indians in general derive their identity based on family and caste membership. The relative low masculinity implies that employees value personalized relationships more than performance. Gopalan and Stahl (1998) have shown that for most, if not all Indians, work is a means to satisfy their family needs. Most of them value relationships and place less emphasis on material goods as they get older. Employment in India is considered to be an extension of social justice (Khandwalla, 1990). Gopalan and Stahl (1998) reporting general absence of strong work ethics in India, further observed that in the Indian context, "keeping people employed appears to be more important than achieving profitability". Hence it is expected that market-oriented organizational cultures such as performance, competitiveness, aggressiveness, outcome orientation and attention to detail to positively moderate the relationship between P-O fit and work attitudes.

Hypothesis 4: Organizational culture moderates the positive relationship between $P-O$ fit and organizational commitment and job satisfaction in such a way that the relationship will be stronger when the culture is more oriented towards market.

Thus given the Indian national culture context, in the presence of organizational cultures which are oriented towards people and control, a weaker relationship between P-O Fit and attitudinal outcomes may be expected, because treating employees with respect 
will be part of organizational schemata and will lead to positive attitudinal outcomes irrespective of the levels of fit. Hence misfit may not significantly affect positive attitudinal outcomes in the cultures where internal constituents - employees - are valued. Whereas market and creation-oriented cultural dimensions may be expected to enhance the positive effects of P-O fit because only those individuals who also share these values will be satisfied, committed and tend to stay in the organization. With respect to organizational reputation, there is no obvious theory or no prior empirical research to support expectations of association with outcomes and hence it is treated as an empirical question. The interaction between national culture, organizational culture and P-O fit is shown in Figure 1.

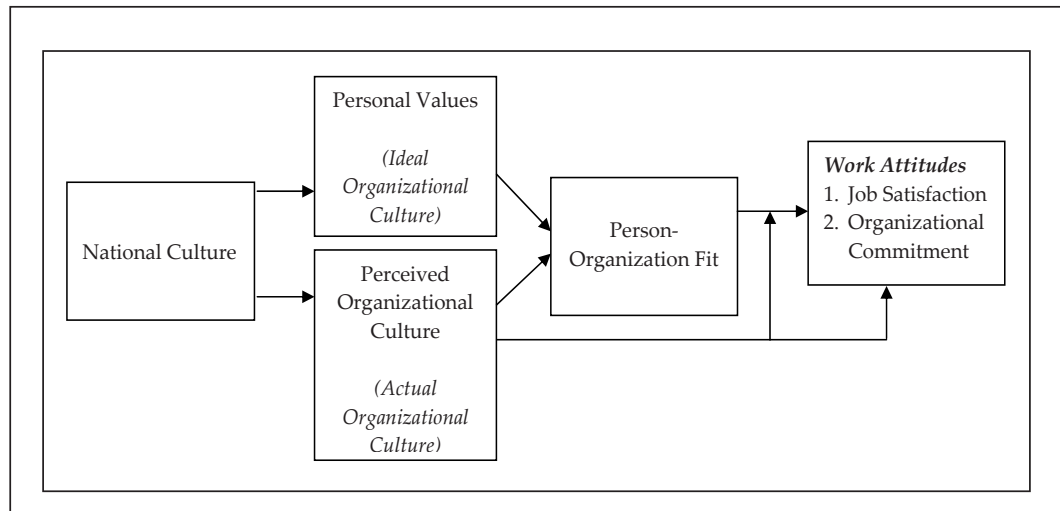

Figure 1. Interaction between national culture, organizational culture and $\mathrm{P}-\mathrm{O}$ fit

\section{Method}

\section{Sample}

The criteria used to select organizations for this study were 1) organization size (workforce size), and 2) the number of years of existence. Organizational culture refers to the values that are widely shared among most of the employees and normally it takes considerable amount of time for the members to accept and practise those values before they get firmed up and embedded in the organizational way of doing things (Schein, 1983). Hence it was decided to select only those organizations which were in existence for more than five years and had a workforce of 100 and more for this study. 
Research on the relationship between industry characteristics and organizational culture suggests that variation in organizational culture may be more across industries than within them (Chatman \& Jehn, 1994). Hence twenty-two organizations were randomly selected initially from different industries located in southern part of India in order to obtain data on varied organizational dimensions. But only seven organizations had agreed to participate in this study. These organizations represented information technology (software development), pharmaceutical, textile manufacturing, marketing consultancy, financial services, and automotive component manufacturing industries The characteristics of the organizations which had participated in this research varied in terms of organization size, total number of years of operation, and management philosophy. The size of the organizations, measured in terms of number of employees, ranged from 250 (financial services) to 1450 (pharmaceutical). The total number of years of operation ranged from 8 to 16 years. Organizational structure ranged from mechanistic to organic. Since organizational culture is shaped by history, structure, and industry characteristics such as technology and growth, the sample of organizations was so chosen to reflect the differences in these parameters.

The sampling strategy was to survey 20-40 employees chosen through the stratified random sampling method from each of the organizations. Stratification was done based on hierarchical level, gender, experience, and functional groups For the purpose of the study, only managerial-level employees who have had a minimum of one-year experience in their respective organizations were chosen to participate in this study. All the respondents were also assured of complete confidentiality and anonymity of their data. Out of 198 filled-in questionnaires, 25 questionnaires could not be used due to incomplete data.

\section{Operationalization of Variables}

Since values are "fundamental and relatively enduring" (Chatman, 1991, pp. 459) and shape organizational culture that guides employees' behaviours (Schein, 1992), this study operationalized P-O fit as the congruence between individual and organizational values. This study used the Organizational Culture Profile (OCP) of O'Reilly et al., (1991) to assess organizational culture and P-O fit. The OCP is based on the Q-sort method (Bem \& Funder, 1978; Block, 1978). The respondents sorted the 54 items into nine categories, ranging from most to least desirable (personal values), or from most to least characteristic (organizational values). To develop a profile of the 
organization's culture, the respondents were asked to sort the 54 value statements according to the extent to which the items were characteristic of the organization. For each organization, a single profile was created by aggregating the individual's perceptions of organizational characteristics. For individual preference, individuals were asked to sort the value items according to their personal preferences for each value in their ideal organization. Then P-O fit score for each individual was measured by correlating the individual preference (ideal) and organizational profile (actual).

Factor analysis of $\mathrm{OCP}$ (actual organizational characteristics) indicated seven organizational culture dimensions: respect for people, stability, innovation, performance orientation, competitiveness, attention to detail, and organizational reputation.

Two measures of work attitudes - job satisfaction, and organizational commitment - were used in this study. Job satisfaction refers to an overall attitude that employees hold toward the job and job context. It may be either positive or negative. Job satisfaction was assessed using a three-item global satisfaction scale adapted from Cammann, Fichmann, Jenkins and Klesh, (1983). Organizational commitment measures the degree to which an individual identifies and is involved in an organization. The affective component of organizational commitment (OC) was used in this study. The affective component of OC refers to an employee's emotional attachment to the organization and it was measured by a nine-item scale adapted from Meyer et al. (1993).

\section{Data Analysis}

The primary objective of this study was to investigate the moderating effect of organizational culture in the relationship between P-O fit and work attitudes. Individual-level hierarchical regression analyses were used to determine whether the effects of P-O fit on the dependent variables are moderated by organizational culture variables A total of 14 hierarchical regressions ( 7 dimensions $\times 2$ dependent variables) were used to test the hypothesis. In each case, the interaction term was added after demographic variables and moderating variables were included in the regression equation.

\section{Moderating Effect of People-Oriented Organizational Cultures}

It was hypothesised that the relationship between P-O fit and work attitudes is weakened by relationship-oriented (people) organization 
culture. Table 1 displays the hierarchical regression models used to test this hypothesis. Four separate regression analyses were performed to maintain sufficient degrees of freedom. In each case, the interaction term was added after control variables, P-O fit and moderating variables were included in the regression equation. If the change in the model $\mathrm{R}^{2}$ is significant (i.e., explains additional variance), then the moderating effect is determined to be significant. Table 1 illustrates that respect for people-oriented organizational culture is a significant moderator of the relationship between P-O fit and job satisfaction and organizational commitment.

Table 1

People-Oriented Organizational Culture Moderated Regression Models

\begin{tabular}{lcccc}
\hline \multirow{2}{*}{ Variables } & \multicolumn{2}{c}{$\begin{array}{c}\text { Job } \\
\text { Satisfaction }\end{array}$} & \multicolumn{2}{c}{$\begin{array}{c}\text { Organizational } \\
\text { Commitment }\end{array}$} \\
\cline { 2 - 5 } & Model 1 & Model 2 & Model 1 & Model 2 \\
\hline Respect for people-oriented culture & $.289^{* *}$ & .245 & $.741^{* *}$ & .641 \\
P-O Fit & $1.457^{* *}$ & 1.145 & $1.77^{* *}$ & 1.045 \\
Respect for People X P-O Fit & & $-1.013^{* *}$ & & $-1.55^{* *}$ \\
$\mathrm{R}^{2}$ & $.441(.406)$ & $.483(.447)$ & $.370(.325)$ & $.468(.427)$ \\
$\mathrm{F}$ & $57.766^{* *}$ & $22.679^{*}$ & $24.65^{* *}$ & $26.10^{* *}$ \\
Change $\mathrm{R}^{2}$ & & .043 & & .098 \\
\hline
\end{tabular}

${ }^{*} \mathrm{p}<.05{ }^{* *} \mathrm{p}<.01$

The results indicate that $\mathrm{P}-\mathrm{O}$ fit influences significantly job satisfaction $(\beta=1.457, \mathrm{p}<.01)$ and organizational commitment $(\beta=1.77, \mathrm{p}<.01)$. In model 2 the respect for people $x \mathrm{P}-\mathrm{O}$ fit interaction term explained weaker relationship with job satisfaction $(\beta=-1.013, p<.01)$ and organizational commitment $(\beta=-1.55, \mathrm{p}<.01)$. Thus Hypothesis 1 , the weakening effect of $\mathrm{P}-\mathrm{O}$ fit on work attitudes in the presence of respect for people culture was supported.

\section{Moderating Effect of Control-Oriented Organizational Culture}

It was hypothesized that the relationship between P-O fit and work attitudes is weakened by control-oriented organization culture. Table 2 displays the hierarchical regression models used to test this hypothesis. The results indicate that $\mathrm{P}-\mathrm{O}$ fit influences significantly job satisfaction $(\beta=1.5, p<.01)$ and organizational commitment $(\beta=1.43, \mathrm{p}<.01)$. In model 2 the stability $x$ P-O fit interaction term explained weaker relationship with job

IJMS 18 (1), 71-97 (2011) 
satisfaction $(\beta=-1.084, p<.01)$ and organizational commitment $(\beta=-.942, \mathrm{p}<.01)$. Thus Hypothesis 2 , the weakening effect of $\mathrm{P}-\mathrm{O}$ fit on work attitudes in the presence of stability culture was supported.

Table 2

Control-Oriented Organizational Culture Moderated Regression Models

\begin{tabular}{|c|c|c|c|c|}
\hline \multirow{2}{*}{ Variables } & \multicolumn{2}{|c|}{$\begin{array}{c}\text { Job } \\
\text { Satisfaction }\end{array}$} & \multicolumn{2}{|c|}{$\begin{array}{c}\text { Organizational } \\
\text { Commitment }\end{array}$} \\
\hline & Model 1 & Model 2 & Model 1 & Model 2 \\
\hline Stability-oriented culture & $.224^{* *}$ & .123 & $.146^{* *}$ & .0965 \\
\hline P-O Fit & $1.5^{* *}$ & & $1.43^{* *}$ & 1.047 \\
\hline Stability X P-O Fit & & $-1.084^{* *}$ & & $-.942^{* *}$ \\
\hline $\mathrm{R}^{2}$ & $.456(.422)$ & $.504(.470)$ & $.407(.369)$ & $.443(.404)$ \\
\hline $\mathrm{F}$ & $70.035^{* *}$ & $13.774^{*}$ & $71.304^{* *}$ & $9.251^{*}$ \\
\hline Change $\mathrm{R}^{2}$ & .266 & .048 & .296 & .036 \\
\hline
\end{tabular}

${ }^{*} \mathrm{p}<.05{ }^{* *} \mathrm{p}<.01$

Table 3

Creation-Oriented Organizational Culture Moderated Regression Models

\begin{tabular}{lcccc}
\hline \multirow{2}{*}{ Variables } & \multicolumn{2}{c}{$\begin{array}{c}\text { Job } \\
\text { Satisfaction }\end{array}$} & \multicolumn{2}{c}{$\begin{array}{c}\text { Organizational } \\
\text { Commitment }\end{array}$} \\
\cline { 2 - 5 } & Model 1 & Model 2 & Model 1 & Model 2 \\
\hline Innovation-oriented culture & $.451^{* *}$ & $.354^{* *}$ & .016 & 0.004 \\
P-O Fit & $1.57^{* *}$ & & $1.08^{* *}$ & \\
Innovation X P-O Fit & & $3.077^{* *}$ & & $2.497^{* *}$ \\
$\mathrm{R}^{2}$ & $.449(.415)$ & $.480(.443)$ & $.415(.378)$ & $.451(.395)$ \\
& & & & \\
F & $61.179^{* *}$ & $18.357^{*}$ & $69.65^{* *}$ & $11.601^{*}$ \\
Change $\mathrm{R}^{2}$ & .236 & .031 & .285 & .036 \\
\hline
\end{tabular}

$*$ p $<.05 * * p<.01$

\section{Moderating Effect of Creation-Oriented Organizational Culture}

Hypothesis 3 proposed that the relationship between $\mathrm{P}-\mathrm{O}$ fit and job satisfactionandorganizationalcommitmentisstrengthenedbycreationoriented culture. Table 3 displays the hierarchical regression models used to test the hypotheses. The results indicate that $\mathrm{P}-\mathrm{O}$ fit influences significantly job satisfaction $(\beta=1.57, \mathrm{p}<.01)$ and organizational 
commitment $(\beta=1.08, \mathrm{p}<.01)$. In model 2 the innovation $\times \mathrm{P}-\mathrm{O}$ fit interaction term explained stronger relationship with job satisfaction $(\beta=3.077, \mathrm{p}<.01)$ and organizational commitment $(\beta=2.497, \mathrm{p}<$ .01 ). Thus Hypothesis 3 , the strengthening effect of $\mathrm{P}-\mathrm{O}$ fit on work attitudes in the presence of creation culture was supported.

Table 4

Market-Oriented Organizational Culture Moderated Regression Models

\begin{tabular}{|c|c|c|c|c|}
\hline \multirow[t]{2}{*}{ Variables } & \multicolumn{2}{|c|}{$\begin{array}{c}\text { Job } \\
\text { Satisfaction }\end{array}$} & \multicolumn{2}{|c|}{$\begin{array}{c}\text { Organizational } \\
\text { Commitment }\end{array}$} \\
\hline & Model 1 & Model 2 & Model 1 & Model 2 \\
\hline Performance orientation & $.290^{*}$ & $.194^{*}$ & .227 & .217 \\
\hline P-O Fit & $1.057^{*}$ & $.864^{*}$ & $.904^{*}$ & .742 \\
\hline Performance orientation X P-O Fit & & $5.578^{*}$ & & $4.796^{*}$ \\
\hline $\mathrm{R}^{2}$ & $.452(.418)$ & $.481(.434)$ & $.401(.363)$ & $.431(.374)$ \\
\hline $\mathrm{F}$ & $53.081^{* *}$ & $12.268^{*}$ & $50.51^{* *}$ & $14.964^{*}$ \\
\hline Change $\mathrm{R}^{2}$ & .203 & .029 & .212 & .030 \\
\hline \multicolumn{5}{|l|}{ Constant } \\
\hline Competitiveness & .243 & .145 & -.074 & -.047 \\
\hline P-O Fit & $.820^{* *}$ & $.645^{*}$ & $.348^{*}$ & .314 \\
\hline Competitiveness X P-O Fit & & $1.281^{* *}$ & & $.967^{*}$ \\
\hline $\mathrm{R}^{2}$ & $.441(.406)$ & $.478(.419)$ & $.395(.357)$ & $.419(.369)$ \\
\hline $\mathrm{F}$ & $60.176^{* *}$ & $24.802^{*}$ & $61.2^{* *}$ & $20.672^{*}$ \\
\hline Change $\mathrm{R}^{2}$ & .235 & .037 & .259 & .024 \\
\hline Attention to detail & -.079 & -.056 & $-.237^{*}$ & -.241 \\
\hline P-O Fit & $.159^{*}$ & -.074 & $.300^{*}$ & -.274 \\
\hline Attention to Detail X P-O Fit & & $.854^{* *}$ & & $1.035^{* *}$ \\
\hline $\mathrm{R}^{2}$ & $.470(.436)$ & $.504(.469)$ & $.421(.384)$ & $.471(.434)$ \\
\hline $\mathrm{F}$ & $72.015^{* * *}$ & $9.832^{*}$ & $70.288^{* *}$ & $13.544^{* *}$ \\
\hline Change $\mathrm{R}^{2}$ & .267 & .034 & .285 & .050 \\
\hline Organizational reputation & $.266^{*}$ & $.212^{*}$ & $.853^{* *}$ & $.745^{*}$ \\
\hline P-O Fit & $1.71^{* *}$ & $1.44^{*}$ & $2.73^{* *}$ & $1.95^{*}$ \\
\hline Organizational Reputation X P-O Fit & & $3.31^{* *}$ & & $3.27^{* *}$ \\
\hline $\mathrm{R}^{2}$ & $.447(.412)$ & $.474(.425)$ & $.386(.347)$ & $.412(.359)$ \\
\hline $\mathrm{F}$ & $66.13^{* *}$ & 12.786 & $53.1^{* *}$ & 17.03 \\
\hline Change $\mathrm{R}^{2}$ & .256 & .027 & .228 & .026 \\
\hline
\end{tabular}

${ }^{*} \mathrm{p}<.05{ }^{* *} \mathrm{p}<.01$

88 IJMS 18 (1), 71-97 (2011) 


\section{Moderating Effect of Market-Oriented Organizational Cultures}

Hypothesis 4 proposed that the relationship between P-O fit and job satisfaction and organizational commitment is strengthened by market-oriented culture. Table 4 displays the hierarchical regression models used to test the hypotheses.

With respect to performance-oriented culture, the results indicate that $\mathrm{P}-\mathrm{O}$ fit influences significantly job satisfaction $(\beta=1.057, \mathrm{p}<$ $.05)$ and organizational commitment $(\beta=.904, \mathrm{p}<.05)$. In model 2 the performance orientation $\times \mathrm{P}-\mathrm{O}$ fit interaction term explained stronger relationship with job satisfaction $(\beta=5.578, \mathrm{p}<.05)$ and organizational commitment $(\beta=4.796, \mathrm{p}<.05)$.

With respect to competitiveness-oriented culture, the results indicate that $\mathrm{P}-\mathrm{O}$ fit influences significantly job satisfaction $(\beta=.820, \mathrm{p}<$ $.01)$ and organizational commitment $(\beta=.348, \mathrm{p}<.05)$. In model 2 the competitiveness $\times \mathrm{P}-\mathrm{O}$ fit interaction term explained stronger relationship with job satisfaction $(\beta=1.281, \mathrm{p}<.01)$ and organizational commitment $(\beta=.967, \mathrm{p}<.05)$.

With respect to attention to detail-oriented culture, the results indicate that $\mathrm{P}-\mathrm{O}$ fit influences significantly job satisfaction $(\beta=.159$, $\mathrm{p}<.05)$ and organizational commitment $(\beta=.300, \mathrm{p}<.05)$. In model 2 the attention to detail $\times \mathrm{P}-\mathrm{O}$ fit interaction term explained stronger relationship with job satisfaction $(\beta=.854, \mathrm{p}<.01)$ and organizational commitment $(\beta=1.035, \mathrm{p}<.01)$.

With respect to organizational reputation-oriented culture, the results indicate that $\mathrm{P}-\mathrm{O}$ fit influences significantly job satisfaction $(\beta=1.71$, $\mathrm{p}<.01)$ and organizational commitment $(\beta=2.73, \mathrm{p}<.01)$. In model 2 the organizational reputation $\times \mathrm{P}-\mathrm{O}$ fit interaction term explained stronger relationship with job satisfaction $(\beta=3.31, \mathrm{p}<.01)$ and organizational commitment $(\beta=3.27, \mathrm{p}<.01)$. Thus Hypothesis 4 , the strengthening effect of $\mathrm{P}-\mathrm{O}$ fit on work attitudes in the presence of market cultures was supported.

\section{Key Findings}

The results suggest that the positive effects of $\mathrm{P}-\mathrm{O}$ fit on job satisfaction and organizational commitment are weakened by people-and control-oriented cultures, whereas creation-and market-oriented organizational cultures strengthened the positive effects of P-O fit on job satisfaction and organizational commitment. 


\section{Limitations}

The main limitation of this study is the reduced sample size for calculating cross-level actual P-O fit. Unfortunately, this was largely due to the use of the OCP and the Q-sort methodology. As described earlier, using Q-sort methodology involves intensive personal interviewing and time on the part of the respondents. The respondents had to sort all the fifty-four value statements into nine categories two times. This has largely restricted the possibility of involving a large number of respondents. Moreover, data was collected only from managerial-level employees who have had a minimum of one year experience in their respective organizations. This has further reduced the potential number of respondents in each organization. In spite of this limitation, this research has a number of strengths. First, this study used the commensurate measurement method to assess $\mathrm{P}-\mathrm{O}$ fit. The commensurate measurement method allows oneself to describe both person and organization with the same characteristics (values) thus increasing mutual relevance of the characteristics under investigation. Kristof (1996) suggested the commensurate measurement method for assessing supplementary fit such as fit between the person and the organization's characteristics. Second, this study has used the ipsative method to assess the actual and the ideal organizational culture which is better than the likerttype scale because it is less prone to a social desirability bias.

\section{Conclusion}

This study examined how environmental factors affect the positive relationship between P-O fit and work attitudes. Specifically it was hypothesized that $\mathrm{P}-\mathrm{O}$ fit would lose its salience in predicting work attitudes under the influence of people-and control-oriented organizational cultures in the Indian cultural context. Further it was also hypothesized that creation and market oriented organizational cultures would strengthen the positive relationship between P-O fit and work attitudes. The results provide support to all the hypotheses and thus show preliminary evidence that environmental factors can strengthen or mitigate the effects of P-O fit. Further the results of this study have theoretical implications for research on moderators of $\mathrm{P}-\mathrm{O}$ fit and to explore these, the results are reviewed in the light of initial expectations.

\section{Implication for Theory}

Researchers in the organizational behaviour field have frequently argued that $\mathrm{P}-\mathrm{O}$ fit is positively associated with work attitudes

90 IJMS 18 (1), 71-97 (2011) 
(Chatman, 1989; O'Reilly et al., 1991). However, our results, along with evidence from other studies suggest that the effects of P-O fit are contingent upon organizational culture dimensions and, more importantly, their alignment with national culture. More specifically, this study provides an empirical evidence for the weakening effects of P-O fit in the presence of people and stabilityoriented organizational cultures. People and stability-oriented organizational cultures are isomorphic with Indian national culture which is characterised by relatively low individualism, and high uncertainty avoidance (Kanungo \& Mendonca, 1994). However, P-O fit's effect on work attitudes was strengthened by innovation, performance, competitiveness, and attention to detail cultures. These cultures are non-isomorphic with Indian national culture in character. With reference to organizational reputation culture, there was no hypothesised relationship but this study explored this as an empirical question. Results suggest that organizational reputation culture strengthened the positive relationship between P-O fit and work attitudes. Since organizational reputation culture is neither isomorphic nor diametrically opposite to Indian national culture values, we may extend the same logic used in non-isomorphic cultures in interpreting its interaction with $\mathrm{P}-\mathrm{O}$ fit. Kristof and Jansen (2007) in their review on moderators of P-O fit effects pointed out that "what is missing at this point is a strong, theory-based rationale for what individual, environmental, and other factors that are likely to influence the impact of P-O fit on individual outcomes" (pp. 128). This study contributed in this direction by developing a theoretical model for the impact of environmental factors such as organizational culture and national culture on $\mathrm{P}-\mathrm{O}$ fit and empirically testing it.

\section{Implications for Managerial Practice}

For management practitioners, this research has several implications. More specifically, insights from this study can be used in the areas of employee recruitment and socialization practices. Organizations, depending on their strategy, structure and control systems, may want to emphasize particular sets of values (culture dimensions) among its employees. If these values are congruent with national cultural values, then P-O fit becomes redundant. In such case, it is sufficient to strengthen their own cultures since they themselves would predict positive work atttidues whereas if the values are incongruent, it is important to focus on P-O fit.

Further, organizations, depending on their strategy, may perceive certain aspects of national culture either to be functional or dysfunctional in getting the appropriate employee behaviour.

IJMS 18 (1), 71-97 (2011) 91 
$\mathrm{P}-\mathrm{O}$ fit assumes more importance, if organizations decide to erase or at least diminish the effects of the dysfunctional values that are embedded in the national culture. In such cases, they may choose to strengthen their own culture so that it will have an overriding effect on employees' behaviour. For example, in India if an organization desires to encourage meeting deadlines, punctuality, risk taking, and open communication between managers and subordinates among its employees, it has to overcome the effects of national culture that may reinforce inappropriate behaviour. In such a case, increasing the levels of P-O fit may help organizations to make their employees exhibit the right behaviour.

More specifically, in the Indian cultural context, if an organization intends to develop cultures that are oriented towards innovation, performance, competitiveness, and attention to detail cultures, hiring for fit with the organization's culture assumes more significance. Since national culture influences an individual's work-related values (Hofstede, 1980), cognitive frames and attitudes (Laurent, 1986), these organizations may use selective hiring, systematic socialization and reward practices to counteract the influence of national culture on individual behaviour. These organizations may select only those who appear to hold values that match with their own, socialize them further to strengthen those common values, and reward them for exhibiting those values in their organizational activities. P-O fit may get salience in this process and thus predicts work attitudes positively.

Managers in such organizations may use the three-step model as described by Bowen, Ledford and Nathan, (1991) to select employees to ensure high levels of P-O fit. Ensuring a proper fit will enhance the organization in the long term. Organizations with a strong orientation towards people, stability and organizational reputation orientation would not have to invest as much in selecting those that fit, because it is not important. In addition to selection methods, socialization activities should also be planned according to the relevance of P-O fit in a particular organization.

Results of this study suggest a number additional research questions which may be investigated in future. Only a few organizations were selected for this study because they seemed to emphasise different organizational cultures by being in different industries.

Such sampling strategy might decrease predictive ability of organizational culture, $\mathrm{P}-\mathrm{O}$ fit variables as well as interaction variables. However, replicating this study with a larger sample of firms chosen

92 IJMS 18 (1), 71-97 (2011) 
from different industries would improve generalizability of the findings. Since the characteristics of Indian national culture alone are used in this study to deduce specific hypotheses, the present study can be classified as an ethnocentric approach (Adler, 1983) in crosscultural management research. Ethnocentric type of studies assume that management theories are culture specific; thus questioning their universal application. Since the present study provides preliminary evidence supporting such assumption, by showing the interaction effects of $\mathrm{P}-\mathrm{O}$ fit and national culture, future research studies can be designed in line with a polycentric approach where the universality is denied. Comparative data collected from organizations located in two or more countries would strengthen the findings of this study.

\section{References}

Adler, N. J. (1983). A typology of management studies involving culture. Journal of International Business Studies, 14, 29-47.

Adler, N. J. (1997). International dimensions of organizational behavior. Cincinnati, OH: South-Western Publishing.

Aldrich, H. E. (1979). Organizations and environments. Englewood Cliffs, NJ: Prentice Hall.

Argyris, C. (1964). Integrating the individual and the organization. New York: John Wiley \& Sons.

Bem, D. J., \& Funder, D. C. (1978). Predicting more of the people more of the time: Assessing the personality of situations, Psychological Review, 85(6), 485-501.

Bowen, D. E., Ledford, G. E., \& Nathan, B. R. (1991). Hiring for the organization, not the job. Academy of Management Executive, 5, 35-51.

Block, J. (1978). The Q-sort method in personality assessment and psychiatric research. Palo Alto, CA: Consulting Psychologist Press.

Budhwar, P., \& Sparrow, P. (2002). Strategic HRM through the cultural looking glass: Mapping cognitions of British and Indian HRM managers. Organization Studies, 23(4), 599-638.

Cable, D. M., \& Judge, T. A. (1996). Person-organization fit, job choice decisions, and organizational entry. Organizational Behavior and Human Decision Processes, 67(3), 294-311.

Cable, D. M., \& Judge, T. A. (1997). Interviewers' perceptions of person-organization fit and organizational selection decisions. Journal of Applied Psychology, 82(4), 546-561.

Cable, D. M., \& Parsons, C. K. (2001). Socialization tactics and personorganization fit. Personnel Psychology, 54, 1-22. 
Cammann, C., Fichman, M., Jenkins, G. D. Jr., \& Klesh, J. R. (1983). Assessing the attitudes and perceptions of organizational members. In S. E. Seashore, E. E. III, Lawler, P. H. Mirvis \& C. Cammann (Eds), Assessing organizational change: A guide to methods, measures, and practices (71-138). New York: John Wiley \& Sons.

Chatman, J. A. (1989). Improving interactional organizational research: A model of person-organization fit. Academy of Management Review, 14(3), 333-349.

Chatman, J. A. (1991). Matching people and organizations: Selection and socialization in public accounting firms. Administrative Science Quarterly, 36, 459-484.

Chatman, J. A., \& Jehn, K. A. (1994). Assessing the relationship between industry characteristics and organizational culture: How different can you be? Academy of Management Journal, 37, 522-553.

DiMaggio, P. J., \& Powel, W. W. (1983). The iron cage revisited: Institutional isomorphism and collective rationality in organizational fields. American Sociological Review, 48, 147-160.

Edwards, J. R. (1991). Person-job fit: A conceptual integration, literature review and methodological critique. International Review of Industrial/Organizational Psychology, 6, 283-357.

Enz, C. A. (1988). The role of value congruity in intraorganizational power. Administrative Science Quarterly, 33, 284-304.

Friedman, M., \& Friedman, R. (1980). Free to choose: A personal statement. New York: Harcourt Brace Jovanovich.

Gordon, G. (1991). Industry determinants of organizational culture. Academy of Management Review, 16, 396-415.

Gopalan, S., \& Stahl, A. (1998). Applications of American management theories and practices to the Indian business environment: Understanding the impact of national culture. American Business Review, 16(2), 30-41.

Government of India (2009). Economic survey 2008-09. New Delhi: Ministry of Finance.

Griffeth, R.W., Hom, P.W., \& Gaertner, S. (2000). A meta-analysis of antecedents and correlates of employee turnover: Update, moderator tests, and research implications for the next millennium. Journal of Management, 26(3), 479.

Griffith, J. (2001). Do satisfied employees satisfty customers? Supportservices staff morale and satisfaction among public school administrators, students, and parents. Journal of Applied Social Psychology, August, 1627-1658.

Guzzo, R., \& Salas, E. (Eds.). (1995). Team effectiveness and decision making in organizations. San Francisco: Jossey-Bass.

94 IJMS 18 (1), 71-97 (2011) 
Hampden-Turner, C., \& Trompenaars, A. (1993). The seven cultures of capitalism. New York: Currency-Doubleday.

Harter, J. K., Schmidt, F. L., \& Johnson, R. (2002). Business-unit level relationship between employee satisfaction, employee engagement, and business outcomes: A meta-analysis. Journal of Applied Psychology, April, 268-279.

Hofstede, G. (1980). Culture's consequences: International differences in work-related values. Beverly Hills: Sage Publications.

Hofstede, G. (1985). The interaction between national and organizational value systems. Journal of Management Studies, 22, 347-357.

Hofstede, G. (1991). Culture's consequences: Software of the mind. London: McGraw-Hill.

Hofstede, G. (2001). Culture's consequences: Comparing values, behaviors, institutions, and organizations across nations (2nd ed.). Thousand Oaks, CA: Sage Publications.

Holland, J. L. (1985) Making vocational choices: A theory of careers (2nd ed.). Englewood Cliffs, NJ: Prentice Hall.

Jabes, J., \& Gruere, J. P. (1986). Organizations under siege: The onslaught of cultural explanations of organizational behavior. Growth and progress in cross-cultural psychology: Selected papers from the $8^{\text {th }}$ International conference of the International association for cross-cultural psychology, Istanbul, Turkey, July 6-10.

Kanungo, R. N., \& Mendonca, M. (1994). Culture and performance improvement. Producitivity, 35(3), 447-53.

Katz, D., \& Kahn, R. L. (1966). The social psychology of organizations. New York: John Wiley \& Sons.

Khandwalla, P. N. (1990). Strategic developmental organizations: Some behavioral properties. In A. M. Jaeger, \& R. N. Kanungo (Eds.), Management in developing countries. New York: Routledge.

Kristof, A. L. (1996). Person-organization fit: An integrative review of its conceptualizations, measurement, and implications. Personnel Psychology, 49, 1-49.

Kristof, A. L., \& Jansen, K. J. (2007). Issues of person-organization fit. In C, Ostroff, \& T. A. Judge (Ed.), Perspectives on organizational fit (pp. 123-153). New York: Francis \& Taylor.

Laurent, A. (1986). The cross-cultural puzzle of international human resource management. Human Resource Management, 25(1), 91-102.

Lewin, K. (1951). Field theory in social science. New York: Harper \& Row.

Locke, E. A. (1976). The nature and causes of job satisfaction. In Marvin D. Dunnette (Ed.), Handbook of Industrial and Organizational Psychology (pp. 1297-1349). Chicago: Rand McNally.

IJMS 18 (1), 71-97 (2011) 95 
McKinnon, J. L., Harrison, G. L., Chow, C. W., \& Annue, Wu. (2003). Organizational culture: Association with commitment, job satisfaction, propensity to remain, and information sharing in Taiwan. International Journal of Business Studies, 11(1), 25-44.

Mathieu, J. E., \& Zajac, D. M. (1990). A review and meta-analysis of the antecedents, correlates, and consequences of organizational commitment. Psychological Bulletin, 108, 171-194.

Meyer, J. P., Allen, N. J., \& Smith, C. A. (1993). Commitment to organizations and occupations: Extension and test of a threecomponent conceptualization. Journal of Applied Psychology, 78, 538-551.

Meyer, J. W., \& Rowan, B. (1977). Institutionalized organization: Formal structure as myth and ceremony. American Journal of Sociology, 83, 340-363.

Mowday, R. T., Steers, R. M., \& Porter, L. W. (1979), The measurement of organizational commitment. Journal of Vocational Behavior, 14, 224-247.

Nelson, R. E., \& Gopalan, S. (2003). Do organizational cultures replicate national cultures? Isomorphism, rejection and reciprocal opposition in the corporate values of three countries. Organization Studies, 24(7), 1115-1151.

Nyambegera, S. M., Daniels K., \& Sparrow, P. (2001). Why fit doesn't always matter: The impact of HRM and cultural fit on job involvement of Kenyan employees. Applied Psychology: An International Review, 50(1), 109-140.

O’Reilly, C. A., Chatman, J. A., \& Caldwell, D. F. (1991). People and organizational culture: A profile comparison approach to assessing person-organization fit. Academy of Management Journal, 34(3), 487-516.

Pascale, R. (1985). The paradox of corporate culture: Reconciling ourselves to socialization, 2, 26-41.

Pettigrew, A. M. (1979). On studying organizational cultures. Administrative Science Quarterly, 24(4), 570.

Pieper, R. (Ed.) (1990). Human resource management: An international comparison. Berlin: Walter de Gruyter.

Prakash, A. (1994). Organizational functioning and values in the Indian context. In S.R. Henry, Kao, Durganand Sinha, \& Ng Sek-Hong (Eds.), Effective organizations and social values (pp. 193-201). New Delhi: Sage Publications.

Quinn, R. E., \& Rohrbaugh, J. (1983). A spatial model of effectiveness criteria: Towards a competing values approach to organizational analysis. Management Science, 29, 363-377.

96 IJMS 18 (1), 71-97 (2011) 
Raltson D. A., Holt D. H., Terpstra R. H., \& Cheng Y. K. (2008). The impact of national culture and economic ideology on managerial work values: A study of the United States, Russia, Japan and China. Journal of International Business Studies, 39, $8-26$.

Saha, A. (1992). Basic human nature in Indian tradition and its economic consequences. International Journal of Sociology and Social Policy, 12(1-2),1-50.

Saini, D. S., \& Budhwar, P. S. (2004). HRM in India. Managing human resources in Asia-Pacific (pp. 114-137). London: Routledge.

Schein, E. H. (1983). The role of the founder in creating organizational culture. Organizational Dynamics, Summer, 13-28.

Schein, E. H. (1992). Organizational culture and leadership (2nd ed.). San Francisco: Jossey-Bass.

Schneider, B. (1987). The people make the place. Personnel Psychology, 40, 437-543.

Scott, K. D., \& Taylor, G. S. (1985). An examination of conflicting findings on the relationship between job satisfaction and absenteeism: A meta-analysis. Academy of Management Journal, September, 599-612.

Sheridan, J. E. (1992). Organizational culture and employee retention. Academy of Management Journal, 35(5), 1036-1056.

Smith, B. E., \& Thomas, J. M. (1972). Cross-cultural attitudes among managers: A case study. Sloan Management Review, 13, 34-51.

Tripathi, R. C. (1988). Aligning development to values in India. In D. Sinha \& H.S.R. Kao, (Eds.), Social values and Development: Asian perspectives. New Delhi: Sage Publications.

United Nations Development Programme. (2009). Human Development Report. New York.

Weiner, Y. (1988). Forms of value systems: A focus on organizational effectiveness and cultural change and maintenance. Academy of Management Review, 13, 534-545.

Westerman, J. W., \& Sita, V. (2005). A cross-cultural empirical analysis of person-organization fit measures as predictors of student performance in business education: Comparing students in the United States and India. Academy of Management Learning \& Education, 4(4), 409-420.

Wheeler A. R., Buckley, M. R., Halbesleben, J. R. B., Brouer, R. L., \& Ferris, G. R. (2005). The elusive criterion of fit revisted: Toward an integrative theory of multidimensional fit. Research in Personnel and Human Resources Management, 24, 265-304.

Wilkins, A. L., \& Ouchi, W. G. (1983). Efficient cultures: Exploring the relationship between culture and organizational performance. Administrative Science Quarterly, 28, 468-181.

IJMS 18 (1), 71-97 (2011) 